\title{
Prinsip Maslahah Pada Putusan Mahkamah Konstitusi Terhadap Perkawinan Bagi Umat Beragama Dan Penghayat Kepercayaan
}

\author{
Umar Haris Sanjaya, Agus Yudha Hernoko, dan Prawitra Thalib \\ Fakultas Hukum Universitas Islam Indonesia Yogyakarta Indonesia, Mahasiswa Program \\ Doktor Fakultas Hukum Universitas Airlangga Surabaya Jawa Timur Indonesia \\ Fakultas Hukum Universitas Airlangga Surabaya Jawa Timur Indonesia \\ Jln. Tamansiswa No. 158 Yogyakarta Indonesia \\ Jln. Darmawangsa Kampus B Program Magister Ilmu Hukum Unair Surabaya Jawa \\ Timur Indonesia \\ umarharis@uii.ac.id: yudha@fh.unair.ac.id; prawitra@fh.unair.ac.id
}

Received: 30 Desember 2020; Accepted: 7 April 2020; Published: 2 Juni 2021

DOI: 10.20885/iustum.vol28.iss2.art2

\begin{abstract}
This study aims to provide insights on the Constitutional Court Decision Number 97 / PUU / XIV / 2016 on filling-in the space for religion or belief in the Identity Card (KTP) has maslahah value for the community. This can be declared true after an analysis of the objectives and their enforcement in Indonesia has been carried out. Maslahah values are manifested by the certainty of the beliefs contained in the KTP. So that in socializing, the people may know for sure one's religion or belief to guarantee or minimize the occurrence of interfaith and belief marriages. This study uses a normative method with a statutory and conceptual approach. The results of the study conclude that the Constitutional Court's decision has maslahah principles in Islamic thought as it provides recognition of rights, recognition of access to rights to public services, public services on marriage registration as a form of certainty, is an order in the Marriage Law, legal certainty creates rights and obligations for spouses, marriage registration creates protection, the state is obliged to provide protection for its citizens..
\end{abstract}

Key Words: Maslahah principle; penghayat kepercayaan; interfaith marriage

\section{Abstrak}

Penelitian ini mempunyai tujuan untuk memberikan pengetahuan bahwa putusan Mahkamah Konstitusi Nomor 97/PUU/XIV/2016 tentang pengisian kolom penghayat kepercayaan pada Kartu Tanda Penduduk (KTP) mempunyai nilai maslahah bagi masyarakat. Hal ini dapat dinyatakan benar setelah dilakukan analisis terhadap tujuan dan penegakannya di Indonesia. Nilai maslahah terwujud dengan adanya kepastian terhadap keyakinan yang tertuang di dalam KTP. Sehingga dalam bergaul, masyarakat dapat mengetahui secara pasti agama dan kepercayaan sehingga dapat menjamin atau meminimalkan terjadinya perkawinan beda agama dan kepercayaan. Penelitian ini menggunakan metode normatif dengan pendekatan perundang-undangan dan konseptual. Hasil penelitian menyimpulkan bahwa Putusan Mahkamah Konstitusi memiliki prinsip maslahah dalam pemikiran Islam karena memberikan pengakuan hak, pengakuan mendapatkan akses hak untuk pelayanan publik, pelayanan publik pada pencatatan perkawinan sebagai bentuk kepastian, merupakan perintah dalam Undang-Undang Perkawinan, kepastian hukum menimbulkan hak dan kewajiban bagi pasangan, pencatan perkawinan menimbulkan perlindungan, negara wajib memberikan perlindungan bagi warganya.

Kata-kata Kunci : Prinsip maslahah; penghayat kepercayaan; perkawinan umat beragama 


\section{Pendahuluan}

Pada 2016, Mahkamah Konstitusi memutus perkara terhadap judicial review dari Undang-Undang Nomor 23 Tahun 2006 tentang Administrasi Kependudukan sebagaimana telah diubah dengan Undang-Undang Nomor 24 Tahun 2013 tentang Perubahan Atas Undang-Undang Nomor 23 Tahun 2006 tentang Administrasi Kependudukan (selanjutnya disebut Undang-Undangan Administrasi Kependudukan) melalui Putusan MK Nomor 97/PUU/XIV/2016. Putusan ini membuat sebuah terobosan baru di dalam hal administrasi kependudukan, yaitu pencantuman identitas "penghayat kepercayaan" di dalam kolom agama pada kartu tanda penduduk (KTP) yang dikeluarkan oleh Direktorat Jenderal Kependudukan dan Pencatatan Sipil.

Sebelumnya, pencantuman identitas agama pada kolom agama di KTP hanya memfasilitasi 6 agama yang ada Indonesia yaitu agama: ${ }^{1}$ Islam, Kristen, Katolik, Hindhu, Budha, dan Kong $\mathrm{Hu} \mathrm{Cu} .^{2}$ Dengan adanya putusan ini, maka Mahkamah Konstitusi memerintahkan bahwa pencantuman identitas agama dapat ditambah dengan identitas agama yaitu penghayat kepercayaan. Hal ini didasari atas amar putusan MK yang bunyinya adalah menyatakan kata "agama" pada Undang-Undang Administrasi Kependudukan tidak mempunyai kekuatan hukum mengikat secara bersyarat sepanjang tidak termasuk "kepercayaan". Sehingga, terjadi pemaknaan baru yang ada pada Pasal 61 dan 64 UndangUndang Administrasi Kependudukan.

Putusan ini dilatar belakangi atas permohonan dari masyarakat yang menganut aliran kepercayaan di Indonesia, mereka menganggap bahwa UndangUndang Administrasi Kependudukan di dalam pengaturan tentang Kartu Keluarga (KK) dan KTP elektronik tidak memberikan hak mereka. Hal itu jelas dinyatakan pada Pasal 61 ayat (1) dan ayat (2) yang mengatur tentang KK bahwa di dalamnya terdapat keterangan agama, tetapi keterangan tentang agama yang

\section{Pasal 1}

${ }^{1}$ Undang-Undang No.1/PNPS/1965 tentang Pencegahan Penyalahgunaan dan/atau Penodaan Agama.

2 Undang-Undang ini pernah dilakukan permohonan judicial review ke Mahkamah Konstitusi pada tahun 2009, tetapi MK menolak permohonan tersebut melalu Putusan MK No. 140/PUU-VII/2009 hal itu terjadi karena adanya potret pelanggaran hak asasi manusia (HAM) atas nama agama dan keyakinan pada kasus penyebaran faham Ahmadiyah di mana mereka mendapatkan kekerasan, penghinaan, penghasutan karena dianggap melakukan ajaran sesat terhadap agama Islam. 
agamanya belum diakui sebagai agama berdasarkan peraturan Perundangundangan atau bagi penghayat kepercayaan tidak diisi, tetapi tetap dilayani dan dicatat dalam database kependudukan. Disamping KK, pengaturan KTP elektronik juga ditermasuk yang diadukan, yaitu pada Pasal 64 ayat (1) dan ayat (5) dimana KTP elektronik di dalamnya mencantumkan keterangan agama, tetapi pencantuman hanya kepada agama yang sudah diakui berdasarkan ketentuan peraturan perundang-undangan saja. Aliran kepercayaan atau penghayat kepercayaan tidak dapat diakui, kepercayaan mereka tidak dapat dicantumkan di dalam kolom keterangan KTP elektronik.

Salah satu pertimbangan hakim adalah dengan menafsirkan terminologi agama secara konstekstual melalu tiga asas yaitu: asas noscitur a sociis, asas ejusdem generis, dan asas experssio unius exclusion. ${ }^{3}$ Dari ketiga asas ini hakim berpendapat bawah kata agama yang terdapat dalam Undang-Undang Administrasi Kependudukan memiliki pengertian tidak mengikutsertakan kepercayaan sebagai bagian yang percaya terhadap Tuhan Yang Maha Esa.. ${ }^{4}$ Berdasarkan pertimbangan tersebut, hakim memperhatikan keberadaan norma Pasal 61 ayat (1) dan ayat (2) dan Pasal 64 ayat (1) dan ayat (5) UU Administrasi Kependudukan yang menimbulkan ketidakpastian dan ketidakkonsistenan dalam Negara dalam melindungi hak-hak masyarakat. Negara mempunyai tujuan untuk melindungi dan mengakui hak-hak dasar warga, tetapi pada implementasinya justru memberikan kerugian konstitusional bagi warganya. Hal ini terlihat dari pertimbangan hakim yang merujuk pada keterangan dari pemohon di mana mereka mendapatkan hambatan dalam mengakses layanan publik. Layanan publik yang dimaksud adalah para penghayat kepercayaan kesulitan memperoleh KK dan KTP elektronik. Dampak dari hambatan tersebut menjadikan mereka sulit mendapat pekerjaan, sehingga majelis hakim memberikan pertimbangan sebagai perlakuan secara diskriminatif.

3 Artinya (1) adalah satu kata atau istilah harus dikaitkan dengan rangkaiannya, (2) suatu kata atau istilah dibatasi secara khusus dalam kelompoknya, (3) jika suatu konsep digunakan untuk satu hal, maka kata tersebut tidak berlaku untuk hal lain. Putusan MK No. 97/PUU-XIV/2016 hlm. 148.

${ }^{4} \mathrm{Hal}$ ini seperti membuat istilah baru dalam terminologi agama yaitu agama resmi dan agama tidak resmi, lihat pada Muhammad Syafei, Ambiguitas Hak Kebebasan Beragama di Indonesia dan Posisinya Pasca Putusan Mahkamah Konstitusi, Jurnal Konstitusi, Vol. 08, No. 5, Edisi Desember 2011, hlm. 63-64. 
Perkawinan menjadi salah satu hambatan hak yang dialami oleh penghayat kepercayaan, terutama dari sisi pencatatan perkawinan. Dahulu, ${ }^{5}$ penghayat kepercayaan mendapatkan perlakuan tambahan (diskriminasi) untuk mendapatkan kepastian dan pengakuan hukum, sebagaimana tertera pada norma Undang-Undang Administrasi Kependudukan dan peraturan pemerintah sebagai pelaksanaan perkawinan penghayat. ${ }^{6} \mathrm{Hal}$ itu diatur pada Peraturan Pemerintah No. 37 Tahun 2007 Tentang Pelaksanaan Undang-Undang No. 23 Tahun 2006 tentang Administrasi Kependudukan.7 Walaupun dalam pelaksanaan pencatatan Kantor catatan sipil tetap meminta penetapan dari pengadilan untuk dilakukan pencatatan. ${ }^{8}$ Kelengkapan terhadap penetapan pengadilan yang diminta sebagai syarat. Sebagai contoh yang terjadi di Kota Surabaya di mana pemerintah kota Surabaya mengeluarkan Perda No. 5 Tahun 2011 tentang Penyelenggaraan Administrasi Kependudukan, tetapi didalam Pasal 45 tentang pelaporan perkawinan, syarat yang dibutuhkan adalah surat keterangan atau surat perkawinan penghayat yang ditanda tangani oleh pemuka, dalam prakteknya tetap dimintakan penetapan pengadilan. Terhadap hal ini menjadikan warga penghayat kepercayaan mengurung diri untuk melakukan pencatatan perkawinan dengan terbuka, sehingga terpaksa berbohong pada sisi agama. ${ }^{9}$ Pendapat mereka pemerintah masih menganggap bahwa penghayat kepercayaan bukan merupakan agama resmi yang diakui oleh peraturan perundang-undangan. ${ }^{10}$

${ }^{5}$ Sebelum putusan MK, penghayat kepercayaan telah melakukan ritual perkawinannya secara adat mereka tanpa melalui pencatatan perkawinan, untuk dapat dicatatkan baru ada ketentuannya melalui Peraturan Pemerintah Republik Indonesia No. 37 Tahun 2007 pada poin Tata cara perkawinan Penghayat kepercayaan, tetapi pada peraturan ini penghayat kepercayaan masih diberikan prosedur tambahan dari pada pemeluk agama yang lain. Salah satu penghayat kepercayaan yang telah melakukan prosedur sesuai PP ini adalah aliran Sapta Darma. Lutfiyanti Andromeda, Perkawinan Penghayat Kepercayaan Sapta Darma di Surabaya, Studi Efektifitas Pencatatan Perkawinan Menurut Lawrence M. Friedman, Tesis, UIN Sunan Ampel Surabaya, 2020, hlm. 52-56.

${ }^{6}$ Pasal 105 Undang-Undang No. 23 tahun 2006 memerintahkan adanya peraturan pemerintah yang secara khusus mengatur tentang mekanisme perkawinan bagi para penghayat kepercayaan untuk dasar penerbitan akta perkawinan dan pelayanan pencatatan peristiwa penting.

7 Tata cara perkawinan antara lain: (1) dilakukan dihadapan pemuka penghayat kepercayaan, (2) pemuka adalah orang yang ditunjuk oleh organisasi penghayat keprcayaan, (3) pemuka penghayat adalah mereka yang didaftarkan pada kementerian yang terkait untuk membina penghayat kepercayaan.

${ }^{8}$ Pada perkawinan penghayat kepercayaan sapta darma, mereka tetap diminta untuk melakukan permohonan pencatatan perkawinan ke pengadilan lihat pada https://majalah.tempo.co/read/agama/124492/tujuh-petunjukmenuju-waskita, diakses pada 18 September 2020.

${ }^{9}$ Putusan MK No. 97/PUU-XIV/2016, hlm. 14

${ }^{10}$ Perda Kota Surabaya No. 5 Tahun 2011 tentang Penyelenggaraan Administrasi Kependudukan pasal 5. 
Sebagai warga Negara Indonesia, penghayat kepercayaan mempunyai hak untuk mendapatkan kepastian hukum dan memperoleh perlindungan hukum atas perkawinan yang dilakukannya. Kepastian hukum suatu hubungan perkawinan baru akan diakui bila itu merujuk pada Undang-Undang No. 1 Tahun 1974 Tentang Perkawinan (selanjutnya disebut Undang-Undang Perkawinan) pada Pasal 2 yang menyatakan perkawinan sah bila dilakukan menurut hukum masing-masing agama dan kepercayaannya, dan dicatat menurut peraturan perundang-undangan yang berlaku. ${ }^{11}$ Merujuk pada kata pencatatan, maka saat ini hal tersebut tertuju pada Undang-Undang Administrasi Kependudukan dimana perkawinan dinyatakan sebagai salah satu peristiwa penting. ${ }^{12}$ Sehingga untuk dapat memenuhi Pasal 2 Undang-Undang Perkawinan maka secara tidak langsung harus memenuhi norma yang ada pada UndangUndang Administrasi Kependudukan.

Putusan MK No. 97/PUU-XIV/2016, direspon pemerintah dengan menerbitkan revisi peraturan terkait pencatatan perkawinan bagi penghayat kepercayaan. yaitu Peraturan Pemerintah No. 40 Tahun 2019 yang isinya tentang aturan pelaksanaan administrasi kependudukan. Isi dari peraturan ini tidak begitu mengalami perubahan secara signifikan terhadap mekanisme pencatatan perkawinan penghayat sebelumnya. ${ }^{13}$ Di ketentuan ini penghayat kepercayaan yang melakukan perkawinan dihadapan pemuka penghayat dan ditetapkan oleh organisasi penghayat yang terdaftar di kementerian maka dapat dicatatkan di kantor catatan sipil. Hambatan yang dialami sebelumnya tentang identitas dalam KK dan KTP elektronik tidak lagi di terjadi, mengingat penghayat kepercayaan sudah mempunyai identitas yang formal. ${ }^{14}$

11 Dicatat menurut peraturan perundang-undangan dalam hal ini dijelaskan oleh Undang-Undang Perkawinan melalui Peraturan Pemerintah No. 9 Tahun 1975 tentang Pelaksanaan Undang-Undang Perkawinan pasal 2 dan pasal 3 dijelaskan dua (2) lembaga yang diberi kewenangan yaitu Kementerian Agama yang beragama Islam, dan Kantor catatan sipil bagi selain agama Islam.

${ }^{12}$ Lihat pada Undang-Undnag Administrasi Kependudukan pasal 56 ayat (2) Peristiwa penting adalah kelahiran, kematian, perkawinan, perceraian, pengakuan anak, pengesahan anak, pengangkatan anak, perubahan nama, perubahan status kewarganegaraan. perkawinan merupakan peristiwa penting, dan setiap penduduk wajib melaporkan perisitwa tersebut yang dialaminya kepada pemerintah melalui catatan sipil. Lihat juga pada Umar Haris Sanjaya, Hukum Perkawinan Islam Di Indonesia, Seri Buku Ajar, Gama Media, Yogyakarta, 2017, hlm. 173174.

13 Ketentuan yang dimaksud adalah Peraturan Pemerintah No. 37 Tahun 2007 Tentang pelaksanaan Undang-Undang Administrasi Kependudukan.

${ }^{14}$ Masyarakat sudah dapat mengurus KTP dengan kolom aliran kepercayaan yang sebelumnya berstatus agama tertentu atau dikosongkan maka dapat diisi dengan sebutan kepercayaan terhadap Tuhan Yang Maha Esa, 
Organisasi penghayat kepercayaan tetap dituntut keberadaannya oleh Pemerintah didalam melaksanakan ritual perkawinan. Hal ini tidak mungkin dihilangkan mengingat keberadaan penghayat kepercayaan juga perlu diakui dalam bentuk wadah atau organisasi. Terlebih pengakuan terhadap penghayat kepercayaan juga perlu dibuktikan dengan keberadaan kelompok atau organisasi yang bertindak atas nama kepercayaan tersebut. Sama halnya dengan perkawinan bagi umat beragama, mereka juga mempunyai mekanisme tersendiri yang diakui berdasarkan tata cara dan kepercayaan atas rukun dan syarat perkawinan. Seperti Islam memiliki akad antara wali perempuan dan calon mempelai pria, Kristen menganggap perkawinan bersifat kekal, Katolik memberlakukan baptis dalam perkawinan, Hindu menjelaskan bahwa perkawinan adalah wiwaha yang bersifat religious, dan Budha perkawinan diatur oleh pemimpin agama menurut kitab Tripitaka. ${ }^{15}$ Oleh karena itu, tidak salah pemerintah tetap memberikan syarat terhadap perkawinan penghayat yang hendak dicatatkan harus melalui prosedur ritual dari pemuka penghayat yang ditetapkan oleh kelompok atau organisasi yang berhak atau berwenang. ${ }^{16}$ Organisasi yang menaungi penghayat kepercayaan dapat didaftarkan pada instansi kementerian terkait harus memiliki anggota yang lokasinya tersebar dalam 3 wilayah kabupatan atau kota. ${ }^{17}$ Secara tidak langsung pemerintah menghormati anggota dari organisasi penghayat kepercayaan yang terdaftar untuk melakukan pencatatan perkawinan sebagai bentuk perlindungan dan kepastian hukum. Sehingga peran pemerintah dalam melindungi hak masyarakat dapat difungsikan dengan benar.

Putusan ini diputus secara bulat tanpa adanya dissenting opinion dari anggota majelis hakim, artinya pertimbangan pada putusan ini dibuat atas dasar keyakinan untuk melindungi hak konstitusi warga Negara. Untuk itu Putusan Mahkamah Konstitusi ini akan dikaji dalam riset dari sudut pandang perspektif maslahah pada hukum Islam. Penggunaan prinsip maslahah ini digunakan untuk

\footnotetext{
lihat pada https://nasional.tempo.co/read/1178325/begini-prosedur-mendapat-ktp-bagi-penganut-alirankepercayaan diakses pada 17 September 2020.

${ }^{15}$ Hilman Hadikusuma, Hukum Perkawinan Indonesia Menurut: Perundangan Hukum Adat Hukum Agama, Mandar Maju, Bandung, 2003, hlm. 145-149

16 Sebagaimana dijelaskan Peraturan Pemerintah No. 40 Tahun 2019 pasal 81 ayat (2) bahwa organisasi yang terdaftar pada instansi Kementerian yang membidangi teknis pembinaan kepercayaan kepada Tuhan Yang Maha Esa.

17 Sukirno, Rekonstruksi Pencatatan Perkawinan Bagi Penghayat Kepercayaan Komunitas Adat, Jurnal Hukum Progresif, vol. 7 No.2 edisi Oktober 2019, hlm. 138.
} 
mencari tahu apakah putusan MK tersebut benar memberikan solusi dan manfaat bagi warga Negara Indonesia khususnya penghayat kepercayaan dalam konteks pencatatan perkawinan.

\section{Rumusan Masalah}

Berdasarkan uraian latar belakang di atas, maka rumusan masalah yang akan dikaji pada penelitian ini yaitu apakah benar putusan Mahkamah Konstitusi No. 97/PUU-XIV/2016 memberikan solusi dan manfaat sebagaimana prinsip maslahah dalam hukum Islam?

\section{Tujuan Penelitian}

Penelitian ini bertujuan untuk menganalisis dengan prinsip maslahah dan menjelaskan bahwa putusan MK No. 97/PUU-XIV/2016 telah memberikan solusi dan manfaat bagi umat beragama dan penghayat kepercayaan atau belum.

\section{Metode Penelitian}

Penelitian ini menggunakan metode penelitian hukum normatif dengan menggunakan metode kualitatif dalam sifat analisisnya. ${ }^{18}$ Yaitu mengkaji norma, ${ }^{19}$ prinsip hukum maslahah dan pertimbangan yang ada pada putusan MK No. 97/PUU-XIV/2016 dengan tujuan untuk membangun konstruksi atau konsepsi doktrin hukum bahwa implementasi dari putusan MK tersebut merupakan suatu solusi yang berbasis maslahah bagi masyarakat Indonesia. ${ }^{20}$

\section{Hasil Penelitian dan Pembahasan}

Prinsip maslahah merupakan pandangan dari akal sehat manusia dimana pandangan tersebut mendatangkan kebaikan dan menghindarkan suatu keburukan. Sifat dari mendatangkan kebaikan dan menghindarkan keburukan ini ternyata sejalan dengan tujuan dari Islam dalam menetapkan suatu kebenaran. Maslahah sendiri mempunyai arti secara etimologis yaitu manfaat.21 Diartikan

\footnotetext{
18 Soerjono Soekanto, Sri Mamudji, Penelitian Hukum Normatif Suatu Tinjauan Singkat, Raja Grafindo Persada, cet. 10, Jakarta, 2007, hlm. 13.

${ }^{19}$ Sri Mamudji, et, al., Metode Penelitian dan Penulisan Hukum, Badan Penerbit Fakultas Hukum Universitas Indonesia, Jakarta, 2005, hlm. 4

20 Peter Mahmud Marzuki, Penelitian Hukum, Prenada Media Group, Jakarta, 2005, hlm. 35.

${ }^{21}$ Ada beberapa arti secara etimologis dari kata maslahah seperti layak, patut, sesuai, faidah, baik lihat pada Asmawi, Perbandingan Ushul Fiqih, Amzah, Jakarta, 2013, hlm. 126-128.
} 
dalam kata yang lain, maslahah adalah lawan kata dari "mudarat" yaitu suatu hal yang mendatangkan kerugian atau keburukan. ${ }^{22}$ Pemikir Islam menjelaskan bahwa dalam menentukan maslahah tidak boleh lepas dari hakekat atas maslahah itu sendiri, yaitu maslahah harus selalu dihadirkan dalam hal memelihara tujuan dari syariah. Artinya dalam setiap menetapkan suatu hukum maka senantiasa diiringi oleh prinsip maslahah ini. ${ }^{23}$ Yusuf Qordawi menyampaikan, bahwa suatu hukum itu dihadirkan untuk digunakan sebagai pedoman dan acuan oleh umat manusia dalam menjalani kehidupan yang tujuannya tidak lain adalah untuk kebaikan, baik di dunia dan di akhirat. ${ }^{24}$

Gagasan metode maslahah sendiri dikenalkan oleh Imam al-Tirmidzi melalui karya-karyanya dengan sebutan maslahah dan maqasid syariah. ${ }^{25}$ Kemudian dari karya ini dikembangkan oleh ulama-ulama yang lain hingga saat ini menjadi kontemporer. Imam al-Ghazali menjelaskan bahwa maslahah itu harus didasari atas tujuan syariah, bukan melihat dari tujuan atau kehendak manusia. ${ }^{26}$ Adapun ada pemikiran dari Najmuddin At-Thufi yang mengindentifikasi maslahah dari sudut pandang pada akal pikiran manusia (dikenal dengan maslahah atu-thufi). ${ }^{27}$ Pemikiran ini cukup membuat perbedaan dengan pemikir maslahah lainnya dimana pada umumnya hanya mengakui eksistensi maslahah bila beranjak dari dalil Quran dan hadis. Sesungguhnya, Maslahah adalah suatu metode untuk menetapkan hukum syariah, penetapan ini dilakukan dengan menggunakan proses ijtihad. ${ }^{28}$ Oleh karena itu penetapan hlm. 634.

22 Departemen Pendidikan dan Kebudayaan, Kamus Besar Bahasa Indonesia, Balai Pustaka, Jakarta, 1996,

${ }^{23}$ Amir Syarifuddin, Ushul Fiqh Jilid 2 cetakan 4, Kencana, Jakarta, 2008, hlm. 367-370.

24 Yusuf al-Qardawi, al-Ijtihad al-Mu'ashir Baina al-Indibat wa al-Infirat, Dar-al tauzi wa al-Nasyr alIslamiyyah, 1994, hlm. 65-68.

25 Enden Haetami, Perkembangan Teori Maslahah 'Izzu Al-Din Bin Abd Al-Salam dalam Sejarah Pemikiran Hukum Islam, Jurnal Asy-Syari'ah, Vol. 17 No. 1 Edisi April 2015, hlm. 30-31.

26 Ada beberapa tren perkembangan kajian tentang maslahah, diawali dari tren Imam al-Haramyn alJuwaini dengan kitab al-burhannya, tren dari Sayfuddin al-Amidi, tren dari pemikiran Al-Izz ibd Abdissalam dengan tasawwufnya, dan tren dari Ibn Taymiyyah dimana sebagian besar tren tersebut mengedepankan dalil nash sebagai dasar untuk maslahah. Lihat pada Muhammad Harfin Zuhdi, Formulasi teori Al-mashlahah dalam paradigm pemikiran hukum Islam Kontemporer, Proceeding Annual International Conference on Islamic Studies, XIV, STAIN Samarinda, 2014, hlm. 203-205

${ }^{27}$ Imam Fawaid, Konsep pemikiran ath-Thufi tentang Mashlahah sebagai metode istinbath hukum Islam, Jurnal Lisan Al-Hal, Volume 8, No. 2 Edisi Desember 2014, hlm. 293.

${ }^{28}$ Wujud ijtihad saat ini lebih kepada ijtihad kontemporer yang ditunjukkan dengan lahirnya peraturan perundang-undangan, putusan, fatwa yang dilahirkan dari lembaga-lembaga pemerintah ataupun organisasi keagamaan lihat pada Asni, Pemikiran Ijtihad kontemporer yusuf qardhawi dan relevansinya dengan pembaruan hukum islam di Indonesia, Jurnal Al-Adl, Vo. 6 No. 1 edisi Januari 2013, hlm. 11-13. 
hukum dengan metode maslahah tidak boleh bertentangan dengan Al-quran, hadist, dan ijma' karena dapat menjadikan metode maslahah menjadi batal. ${ }^{29}$

Maslahah sendiri dibagi dalam beberapa tingkatan, lingkup, dan tujuannya oleh para ulama hukum Islam, hal itu dikembalikan dari tujuan terhadap syariahnya masing-masing. ${ }^{30}$ Pada konteks putusan MK, maslahah yang dapat dikaji lebih kepada maslahah yang bersifat adanya keserasian antara akal sehat dengan tujuan syariah dalam menetapkan suatu putusan (hukum). Maslahah semacam ini dibagi tiga yaitu maslahah:31 (1) Al-Mu'tabaroh yaitu maslahah yang petunjuknya langsung didapat dari syariah dalam menetapkan hukum. (2) AlMulghoh yaitu maslahah yang tidak diperhatikan dalam syariah atau ada penolakan dalam syariah namun dalam menetapkan hukumnya justru sebaliknya (3) Al-mursalah yaitu manfaat apa yang dipandang baik menurut akal sehat manusia tetapi tidak ada (petunjuk) atau sejalan dengan syariah dalam menetapkan hukum. Dari ketiga penjelasan maslahah diatas, para ulama menetapkan bahwa hanya dua yang dapat dijadikan metode dasar dalam menetapkan argumen hukum, yaitu mashalah mu'tabaroh dan maslahah mursalah. ${ }^{32}$ Sebagian besar ulama menerima kedua metode tersebut sebagai alasan dalam menetapkan hukum.

Dalam menetapkan suatu hukum atau putusan, maka harus ada dalil yang disyaratkan yang mempengaruhi hukum tersebut seperti adanya: ayat alquran, hadist, dan ijma' yang menunjukkan kalau sifat-sifat yang ada pada dalil tersebut dapat dijadikan motivasi untuk menetapkan suatu hukum. Sebelum ditetapkan suatu hukum, ulama akan meninjau ada tidak dalil yang membenarkan atau membatalkan sebagai bentuk alasan dasar kesesuaian dengan tujuan syariah (maqasid syariah). ${ }^{33}$ Mengingat syariah itu dibuat atau diatur pasti mempunyai

${ }^{29}$ Wahbah al-Zuhayli, Ushul al-fiqh al-Islam wa adillatuh, Dar al-fikr, Beirut, 1986, hlm. 155-160.

${ }^{30}$ Dalam hal ini maslahah terbagi atas maslahah yang menggambarkan kekuatan seperti : dharruriyah, hajiyah, dan tahsiniya, dari sisi kandungan ada maslahah al-ammah dan al-khassah. Dari perubahan ada maslahah tetap dan berubah, dari sisi keserasian antara akal dan hukum ada maslahah al mu'tabaroh, mulghoh, dan mursalah. Nasrun Haroen, Ushul Figh 1, cetakan 1, Logos, Jakarta, 1996, hlm. 115-118.

31 Amir Syarifuddin, Op. Cit., hlm. 370-377

32 Pada mu'tabaroh dalilnya perintahnya jelas dalam Al-quran dan hadist, pada mursalah dalilnya belum ada atau tidak dijelaskan untuk itu membutuhkan irisan pengait untuk menguatkan dalam penggunaan metode maslahah mursalah.

33 Wardiyanta, Ijtihad Religius Abmad al-Raisuni, Erlangga, Surabaya, 1995, hln. 70-70. 
tujuan kemanfaatan dan setiap larangan pasti disitu ada ketidakmanfaatan atau bahaya. ${ }^{34}$

Perkembangan hukum saat ini, sudah masuk kepada perubahan peradaban, di mana peradaban baru ini membutuhkan rekonstruksi paradigm yang lebih kontemporer. Artinya memahami nash dalam Al-quran dan hadist membutuhkan teori interpretasi yang mengedepankan realitas untuk menghilangkan aspek negatif (mudharat) dan memilih nilai positif (maslahah). Prinsip maslahah adalah modal besar yang harus dipertahankan dalam mempelajari dan menerapkan hukum-hukum yang diturunkan oleh Tuhan kepada manusia baik itu perkara yang ditetapkan secara eksplisit maupun tidak. Maslahah adalah metode atau alat untuk merangsang daya pikir agar manusia senantiasa dapat menciptakan hukumnya yang relevan dengan zamannya. Sehingga disetiap era, manusia akan selalu dapat mempunyai pedoman hukum yang sejalan dengan syariah bila terus mengedepankan prinsip maslahah. ${ }^{35}$ Dimana prinsip maslahah ini mempunyai 2 pedang ujung tombak untuk dapat mengidentifkasi problem kontemporer yakni mengakomodasi nilai yang positif (mengambil manfaat/ jalb al-mashalih) dan disaat yang bersamaan membuah nilai yang negatif (menolak kerusakan/ dar almafasid).

\section{Pencatatan Perkawinan Sebagai Bentuk Kepastian (Peristiwa Penting) yang Berprinsip Maslahah}

Pencatatan perkawinan bukan merupakan rukun atau syarat sahnya sebuah hubungan perkawinan. Perbuatan ini lebih kepada bentuk adanya sebuah kepastian hukum. ${ }^{36}$ Mengingat perkawinan sejatinya dilakukan dengan menggunakan pendekatan secara cultural, kebudayaan, dan keagamaan. Oleh sebab itu perkawinan dilakukan secara turun temurun oleh mereka yang hanya memiliki kelompok, keluarga untuk mengikatkan hubungan antara laki-laki dan

34 Muhammad Roy Purwanto, "Putusan Mahkamah Konstitusi terhadap pasal 43 ayat (1) UU No. 1 Tahun 1974 tentang status anak di luar nikah berdasarkan mashlahah Najmuddin al-Thufi dekonstruksi undangundang hukum Islam”, Jurnal Al-Mawarid,Vol. 7 Nomor.1 Edisi Feb-Agust 2012, hlm. 85-87.

35 Felicitas Opwis, "Maslaha in Contemporary Islamic Legal Theory", Journal Islamic Law and Society, Vol.12, No. 2, Koninklijke Brill NV, Leiden, 2005, hlm. 180-183.

36 Pendapat ini disampaikan oleh beberapa tokong seperti Bagir Manan, Neng Djubaidah bahwa pencatatan perkawinan merupakan fungsi administrasi, tetapi yang membuat sah adalah akadnya, ijab qobulnya, lihat pada Wasman, Wardah Nuroniyah, Hukum perkawinan Islam di Indonesia, perbandingan fiqih dan hukum positif, teras, Sleman, Yogyakarta, 2011, hlm. 50-51. 
wanita. ${ }^{37}$ Catatan sejarah menunjukkan praktik perkawinan lebih kepada praktik budaya dan adat dimana itu terjadi sebelum abad ke 10. Sekitar abad 10 tersebut mulai didasari kehadiran nilai-nilai agama sebagai tata cara untuk mengesahkan perkawinan. Pada era tersebut perkawinan sah bila dilakukan dengan menggunakan hukum perkawinan di gereja. ${ }^{38}$ Pada abad ke 19 nilai agama mulai dimasukkan kedalam landasan hukum negara-negara seperti di Eropa, hal ini mempunyai arti bahwa nilai agama mulai dimasukkan kedalam hukum konstitusi mereka.

Sejarah menunjukkan bahwa bentuk pencatatan perkawinan mulai diberlakukan sekitar abad ke 18 di willayah Inggris dan negara-negara eropa, hal ini ditunjukkan dengan adanya pencatatan sipil sebagai bentuk pengakuan atas perkawinan yang sudah disahkan oleh agama. ${ }^{39}$ Pada waktu yang bersamaan di abad 18, Kolonial Belanda juga menerapkan ketentuan Burgelijk Wetboek voor Indonesia melalui ketentuan Staatsblad No. 23 Tahun 1847. Ketentuan tersebut mulai diberlakukan setidaknya sejak januari 1848 dengan menerapkan prinsip dan asas-asas yang merujuk pada hukum Belanda. ${ }^{40}$

Sejak Indonesia merdeka, ketentuan mengenai pencatatan perkawinan diatur melalui Undang-Undang No. 22 Tahun 1946 tentang pencatatan nikah, talak, dan rujuk. Tetapi ketentuan ini hanya berlaku bagi wilayah Jawa dan Madura dan belum berlaku untuk seluruh wilayah Indonesia. Baru pada 1954 pemerintah memberlakukan ketentuan pencatatan untuk seluruh wilayah di Indonesia dengan menerbitkan Undang-Undang No 32 Tahun 1954 tentang Pemberlakuan Undang-Undang No. 22 Tahun 1946 untuk diseluruh luar jawa dan Madura. Politik hukum yang dituangkan dalam ketentuan pencatatan nikah, talak, dan rujuk adalah semangat kepastian hukum terhadap dilangsungkannya hubungan perkawinan. Prinsip dasarnya adalah jangan sampai seseorang tidak

\footnotetext{
${ }^{37}$ Caroline Soergjerd, Reconstruction Marriage, The legal status of relationship In changing society, Intersentia, Cambridge, 2012, hlm. 20-24.

${ }^{38}$ Norman Doe, Law and Religion in Europe, A Comparative Introduction, Oxford University press, Oxford, 2011, hlm 1-9

${ }^{39}$ Hal ini sebagai latar belakang perdebatan di dalam penerapan 1753 Marriage act di Inggris, David Lemming, Marriage and The Law In Eighteenth Century, "Hardwicke’s Marriage Act Of 1753", The Historical Journal, Cambridge University press, Volume 39, issues 02, June, 1996, hlm. 340-342.

40 Wirjono Projodikoro, Azas-azas Hukum Perdata, Sumur Bandung, Bandung, cetakan IX, 1983, h. 4-9
} 
tahu bahwa telah terjadi perkawinan terhadap seseorang satu dengan yang lainnya karena ketiadaannya kepastian hukum. Disamping Undang-Undang ini, ketentuan pencatatan perkawinan yang merujuk pada Kitab Undang-Undang Hukum Perdata melalui ketentuan Huwelijksordonnantie S. 1929 No. 348 jo. S. 1931 No. 467, Vorstenlandsche Huwelijksordonnantie S. 1933 No. 98 dan Huwelijksordonnantie Buitengewesten S. 1932 No. 482 tetap berlaku, tetapi pemberlakuan ini hanya bagi mereka yang bukan beragama Islam.

Pada 1974 Pemerintah Indonesia menerbitkan Undang-Undang No. 1 Tahun 1974 tentang Perkawinan, politik hukum yang dibangun dalam ketentuan ini tidak lagi mengedepankan kepastian hukum, tetapi berkembang menjadi alasan perlindungan hukum. Perlindungan hukum ini ditujukan kepada kaum wanita dan anak yang dilahirkan akibat dari hubungan perkawinan. Sehingga peran pencatatan perkawinan terlihat sangat krusial didalam penegakan UndangUndang perkawinan. Mengingat bila perkawinan tidak dicatatkan maka dampaknya akan menimbulkan potensi kerugian bagi pasangan yang melakukan perkawinan khususnya wanita dan anak. ${ }^{41}$ Kerugian itu berupa tidak adanya kepastian dan perlindungan dari negara, mengingat tidak adanya pencatatan maka : (1) tidak ada akta perkawinan, (2) anak yang dilahirkan sukar mendapat akta kelahiran sebagai alat bentuk pengakuan subyek hukum perdata di Indonesia, (3) anak dapat saja dinyatakan tidak memiliki hubungan nasab dengan ayah biologisnya, (4) tidak ada hak dan kewajiban antara suami dan istri yang terikat dimata hukum, (5) tidak dapat menggugat harta bersama dan menuntut hak waris, (6) suami dapat saja menceraikan istri dengan mudah tanpa mekanisme hukum, (7) suami dan istri tidak dapat saling menuntut.

Peran pengadilan pun juga mulai dilibatkan dalam urusan perkawinan melalui Undang-Undang perkawinan, hal ini terlihat pada Peraturan pelaksanaannya dimana pencatatan juga melibatkan lembaga peradilan yaitu pengadilan negeri dan pengadilan agama. Hal ini terjadi mengingat pencatatan perkawinan dilakukan oleh dua (2) lembaga yang berwenang berdasarkan latar belakang keyakinan dari calon mempelai. Bila ia beragama islam maka

${ }^{41}$ Amir Nurudin, Azhari akmal, Hukum Perdata Islam di Indonesia, Kencana Prenada Media Group, Jakarta, 2004, hlm. 120-122. 
pencatatan akan dilakukan oleh kementerian Agama, sebaliknya bila beragama selain islam maka akan dilakukan oleh kantor catatan sipil.42

Pada 2006, pencatatan perkawinan mulai bertransformasi menjadi perbuatan yang mempunyai ruang lingkup publik, hal ini terlihat dari ketentuan yang ada pada Undang-Undang Administrasi Kependudukan yang saat ini telah diamandemen pada 2013 silam. Ada perkembangan signifikan dari tujuan adanya pencatatan dari 1946 hingga 2006 yaitu dari kepastian hukum ke perlindungan hukum menjadi peristiwa penting. Dimana perkawinan yang notabene adalah urusan pribadi seseorang, dengan adanya Undang-Undang ini maka seseorang melakukan perkawinan harus melaporkan perkawinannya.

Hal ini menunjukkan bahwa Konstitusi sudah ikut masuk dalam hubungan manusia yang bersifat personal yaitu hubungan perkawinan, tetapi keberadaan konstitusi lebih kepada upaya untuk mewujudkan tertib administrasi. Tertib administrasi adalah tujuan diterbitkannya Undang-Undang Administrasi Kependudukan, dimana negara dapat mengetahui detail data-data penduduknya. Yang dimaksud data kependudukan antara lain seperti : (1) kelahiran, (2) kematian, (3) lahir mati, (4) perkawinan, (5) perceraian, (6) pengakuan anak, (7) pengesahan anak, (8) pengangkatan anak, (9) perubahan nama, (10) perubahan status kewarganegaraan, (11) peristiwa lainnya yang dianggap penting berdasarkan penetapan pengadilan.

Undang-Undang Administrasi Kependudukan juga mulai mengatur mekanisme dan tata cara pencatatan perkawinan bagi para penghayat kepercayaan secara khusus melalui Peraturan pelaksanaannya yaitu Peraturan Pemerintah No. 37 Tahun 2007. Hal ini dituangkan pada bab X tentang persyaratan dan tata cara yang harus dilakukan adalah:43 (1) melangsungkan perkawinan dihadapan pemuka penghayat kepercayaan, (2) pemuka adalah orang yang ditetapkan sah oleh organisasi dari penghayat, (3) pemuka adalah orang yang terdaftar dalam kementerian yang membina organisasi penghayat kepercayaan. Perkawinan dihadapan pemuka tersebut wajib dilaporkan ke instansi pelaksana khusus

\footnotetext{
${ }^{42}$ Kewenangan Kementerian Agama berdasarkan Undang-Undang No. 32 Tahun 1954, kewenangan Kantor catatan sipil berdasarkan PP No. 9 Tahun 1975.

${ }^{43}$ Pasal 81 dan 82 Peraturan Pemerintah No. 37 Tahun 2007.
} 
penghayat dengan melampirkan syarat-syarat administrasi seperti: surat perkawinan, KTP, foto, akta kelahiran, dan paspor bagi orang asing.

Pelaporan KTP pada syarat pencatatan perkawinan bagi penghayat kepercayaan ini tidak sinkron dengan ketentuan yang ada pada Undang-Undang Administrasi Kependudukan itu sendiri. Letak ketidak sinkronan itu terjadi pada pelampiran KTP sebagai syarat pencatatan perkawinan. Padahal dinyatakan pada Pasal 61 penghayat kepercayaan tidak dicantumkan dalam KTP karena bukan merupakan agama sebagaimana diakui berdasarkan peraturan perundangundangan. Pada prakteknya mereka terpaksa bohong dengan mencantumkan salah satu agama yang diakui pemerintah didalam KTP mereka. ${ }^{44}$ Bila ada kolom agama pada KTP mereka (penghayat kepercayaa) sehingga tidak relevan bila hendak melakukan pencatatan perkawinan dengan mekanisme penghayat kepercayaan mengingat syarat melakukan pencatatan adalah melampirkan KTP. Hal ini menimbulkan potensi ketidak konsistenan bagi pemohon pencatatan perkawinan, secara substansi dan keyakinan ia memeluk aliran kepercayaan tetapi di kolom KTP ia memeluk salah satu agama yang ia sendiri tidak yakini, tetapi ketika hendak melakukan perkawinan dan pencatatan menggunakan mekanisme aliran kepercayaan ia melampirkan KTP dengan kolom agama yang tidak sesuai keyakinannya.

Dengan adanya Putusan MK No. 97/PUU-XIV/2016 yang amar putusannya mengadili bahwa Pasal 61 ayat (2) dan Pasal 64 ayat (5) yang merujuk pada pembuatan KK dan KTP elekronik adalah penggunaan kata "agama" juga termasuk kepada mereka yang mempercayai aliran kepercayaan. Dengan adanya putusan MK ini, maka jelas penghayat kepercayaan memiliki hak yang sama dalam memasukkan keyakinannya didalam KTP elektronik. ${ }^{45}$ Sehingga keterangan keyakinan dalam KTP elektronik akan sama dengan mekanisme pencatatan perkawinan yang akan dilakukan dicatatan sipil, mengingat data

\footnotetext{
44 Sebagian Fakta-fakta menjelaskan bahwa mereka menggunakan agama dalam kolom agama liha pada Putusan MK No. 97/PUU-XIV/2016 hlm. 14

45 Kolom agama di ktp dan kesetaraan hak untuk penghayat kepercayaan, lihat pada http://lipi.go.id/berita/kolom-agama-di-ktp-dan-kesetaraan-hak-untuk-penghayat-kepercayaan/21741 diakses pada 26 September 2020.
} 
mereka telah dimasukkan pada data base kependudukan pada saat pembuatan KTP elektronik. ${ }^{46}$

Telah dijelaskan sebelumnya bahwa politik hukum dari pencatatan perkawinan mengalami 2 kali perkembangan, dimana pertama kali tujuannya adalah kepastian hukum, kemudian berkembang menjadi perlindungan hukum dan berkembang lagi menjadi peristiwa penting yang harus dilaporkan. Dilihat dari tujuan pencatatan perkawinan maka tujuan itu mempunyai nilai yang sama dengan prinsip dalam tujuan syariat islam yaitu kemaslahatan bagi masyarakat. Bila dideskripsikan maka prinsip maslahah yang ditemukan pada pencatatan perkawinan: suatu kewajiban negara untuk memfasilitasi warganya dalam melakukan hubungan perkawinan yang bernilai kepastian sehingga berakibat pada timbulnya hak dan kewajiban dari hubungan tersebut yang dapat diketahui oleh publik karena tercatat dalam data base kependudukan.

Soetandyo berpendapat bahwa perkembangan hukum akan selalu berkembang sesuai dengan perkembangan kekuasaan, komunitas local dari model lama menjadi model baru. Perubahan ini akan membawa suatu negara pada model sistem hukum yang modern, terlebih sifat dari negara modern adalah positif dan pasti. Mau tidak mau maka sesuatu yang belum diatur perlu diatur atau dikodifikasikan. ${ }^{47}$ Pencatatan adalah suatu proses ijtihad yang dilakukan oleh pemerintah Indonesia, tentunya pencatatan tidak terjadi di zaman Rasulullah SAW. Tetapi semangat mencatat ini terjadi karena bagian dari maslahah sesama manusia ketika bermuamalah supaya tidak terjadi keraguan. Hal ini sebagaimana dalil Al-Quran pada surat Al-Baqarah ayat 282, dimana dalam suatu transaksi diperintahkan oleh Allah SWT untuk melakukan pencatatan.

Atas dasar nash Al-Quran inilah pencatatan dirasa sejalan dengan maqasid syariah pada surat Al-Baqarah ayat 282 disamping itu keberadaan pencatatan juga mendatangkan manfaat yang besar dan mengurangi mudharat dalam hal perkawinan. Pencatatan perkawinan adalah perbuatan yang memberikan manfaat

\footnotetext{
46 Peraturan Pemerintah Republik Indonesia No. 40 Tahun 2019 Tentang Pelaksanaan Undang-Undang Administrasi Kependudukan.

47 Soetandyo Wignjosoebroto, Masalah Pluralisme dalam pemikiran dan kebijakan perkembangan bukum nasional, pengalaman Indonesia, makalah seminar nasional pluralisme hukum, Pluralisme hukum perkembangan di beberapa negara, sejarah pemikirannya di Indonesia dan pergulatannya dalam gerakan pembaharuan hukum, Universitas Al-Azhar, Jakarta, 2006, hlm. 1-2
} 
dimana secara rasional dapat diterima oleh seluruh elemen masyarakat tanpa terkecuali, kecuali bagi mereka yang hendak mempermainkan hubungan perkawinan. Bila dianalisa dengan metode maslahah maka pencatatan perkawinan ini telah memenuhi nilai maslahah, yaitu maslahah mursalah seperti : (1) pencatatan perkawinan mendatangkan manfaat, (2) sejalan dengan tujuan syariah yang tidak berbenturan dengan Al-quran, hadis, dan ijma, dan (3) pencatatan justru menghilangkan keragu-raguan dalam hubungan perkawinan dengan timbulnya kepastian dan perlindungan hukum (jalbu mashalih wa dar al mafasid), dan (4) dilakukan melalui proses ijtihad, artinya Undang-Undang Perkawinan dibuat melalui proses yang panjang antara eksekutif dan legislative.

\section{Putusan Mahkamah Konstitusi Sejalan dengan Pasal 2 ayat (1) Undang-Undang Perkawinan Pada Kata "Agama dan Kepercayaannya Masing-masing"}

Putusan MK dalam mengadili permohonan judicial review terhadap UndangUndang Administrasi Kependudukan sepatutnya mempunyai hubungan dengan Pasal 2 ayat (1) pada Undang-Undang Perkawinan. Hubungan itu terletak pada kata bahwa perkawinan dinyatakan sah apabila dilakukan menurut hukum masing-masing agama dan kepercayaannya. Redaksi yang ditulis pada Pasal 2 ayat (1) ini mengilustrasikan bahwa keberadaan keyakinan terhadap aliran kepercayaan itu ada di Indonesia. Tidak dapat dipungkiri bahwa aliran kepercayaan adalah system keyakinan yang asli dan lahir di Indonesia, aliran ini lebih sering dikatakan sebagai aliran kebatinan, aliran kerohanian, bahkan ada yang mencetuskan sebagai aliran kejiwaan. ${ }^{48}$ Keberadaan aliran kepercayaan ini sudah ada sejak dahulu dan mereka turut andil dalam ikut serta memperjuangkan kemerdekaan negara Indonesia.

Setelah Indonesia merdeka, mereka dijadikan korban ditengah-tengah konflik dalam mempertahankan kemerdekaan dari internal bangsa seperti dituduh tidak beragama atau dikatakan kafir, bahkan dituduh sebagai PKI (partai Komunis Indonesia). ${ }^{49}$ Penghayat kepercayaan sendiri bila di data maka akan dapat diketahui bahwa dari masing-masing pulau di Indonesia memiliki

\footnotetext{
${ }^{48}$ Undang-Undang Administrasi Kependudukan memberikan istilah bagi aliran kepercayaan yaitu kepercayaan terhadap Tuhan Yang Maha Esa.

49 Putusan MK No. 97/PUU-XIV/2016 hlm. 120
} 
kelompok/organisasi penghayat kepercayaan. Seperti contoh adalah di sumatera utara adalah purwo madio wasono ugamo malim (parmalim), di Riau ada Batin suku akit, di Lampung ada pendidikan kerohanian luhur (PKL), di Banten ada gayuh urip utami, di Jakarta ada paguyuban ngesti budoyo, di jawa barat ada aliran kepercayaan aji dipa, di jawa tengan ada Pakarti, dan jawa timur ada sapta dharma. ${ }^{50}$ Masing-masing kepercayaan ini sudah diwadahi dan berjalan memiliki organisasi kelompok hingga susunan kepemimpinan organisasinya masingmasing. Penganut aliran kepercayaan menunjukkan eksistensinya dengan mengadakan kongres dan mendirikan Badan Kongres Kebatinan Seluruh Indonesia (BKKI), mereka memberikan pernyataan bahwa aliran kepercayaan bukanlah agama baru namun usaha untuk pengabdian dan rasa keagamaan terhadap masing-masing agama. Mereka juga meminta kepada presiden untuk mensejajarkan aliran kepercayaan dengan agama yang ada. ${ }^{51}$ Berbeda dengan agama yang pengikutnya seiring bertambah, aliran kepercayaan tidak begitu berkembang dalam jumlah pengikutnya karena aliran tersebut tidak disebarluaskan seperti agama-agama yang lain. ${ }^{52}$ Ada yang sudah terdaftar ada yang belum, walaupun terdaftar, tetapi pada prakteknya hak-hak sipil mereka belum diakui dalam urusan keyakinan, sehingga didalam identitas mereka terpaksa menyembunyikan keyakinan aslinya dengan mencantumkan identitas agama yang diakui.

Merujuk pada Pasal 2 Undang-Undang Perkawinan, sejatinya sahnya perkawinan itu terjadi bila dilakukan menurut hukum agama dan kepercayaan. Diketentuan ini menyebutkan ada 2keyakinan yang mengesahkan perkawinan, artinya bila dilakukan berdasarkan prinsip agama dianggap sah, maka berdasarkan kepercayaan juga mempunyai kekuatan yang sama. Substansi dari hubungan perkawinan itu adalah keabsahannya itu sendiri,53 yaitu dasar disahkannya perkawinan. Bila perkawinan sudah dilakukan atas dasar akidah

${ }^{50}$ Gomgom T. Siregar, et all, "Kebangkitan hak-hak sipil penghayat kepercayaan parmalim pasca pasal 61 ayat (1) putusan Mahkamah Konstitusi nomor 97 /PUU-XIV/2016 di Kota Medan”, Jurnal Rectum, volume 2, nomor 2, edisi Juli 2020, hlm. 76,

${ }^{51}$ Lutfiyanti Andromeda, Op., Cit., hlm. 45.

52 Bahkan organisasi Parmalim sudah terdaftar resmi di Kementerian Pendidikan dan Kebudayaan sejak tahun 1980 melalui ketetapan nomor I/136/F3/N.1.1/1980, Ibid, hlm. 77

53 Saleh K. Watjik, Hukum Perkawinan Indonesia, Ghalia, Jakarta, hlm. 15. 
agama dan kepercayaan walaupun belum dilakukan pencatatan sepatutnya ini dilindungi oleh Konstitusi, karena sudah sah perkawinannya berdasarkan Pasal 2 ayat (1). ${ }^{54}$

Pasal 2 Undang-Undang Perkawinan adalah pasal yang menentukan sah tidaknya suatu hubungan perkawinan, sepanjang perkawinan dinyatakan sah oleh ketentuan hukum/lembaga/organisasi yang benar maka keabsahan perkawinan tersebut harus dicatatkan menurut peraturan perundang-undangan. Pencatatan perkawinan bagi umat beragama merujuk pada Undang-Undang Perkawinan, tetapi bagi penghayat kepercayaan mekanisme tersebut merujuk pada Undang-Undang Administrasi Kependudukan melalui peraturan pelaksanaannya. Pencatatan perkawinan bagi penghayat kepercayaan terbentur 2 halangan yaitu : (1) tidak diakuinya kepercayaan sebagai agama, mengingat yang dapat dicatat adalah umat beragama,55 (2) ketidakharmonisan aturan pada pencantuman kolom agama pada identitas, mengingat adanya penghayat kepercayaan yang terpaksa bohong dalam mengisi kolom agama atau ketidaktahuan mereka tentang agama. ${ }^{56}$

Sengan adanya Putusan MK, penggunaan kata agama di dalam UndangUndang Administrasi Kependudukan harus diikutsertakan pula didalamnya adalah kepercayaan, sehingga perkawinan bagi penghayat kepercayaan yang sah harus dicatatkan menurut peraturan perundang-undangan yang berlaku. Putusan MK ini sejalan dengan ketentuan semangat yang ada pada Pasal 2 ayat (1) Undang-Undang Perkawinan.Dijelaskan sebelumnya bahwa Undang-Undang Perkawinan mempunyai tujuan sebagai perlindungan hukum bagi pasangan perkawinan, khususnya bagi kaum wanita dan anak yang dilahirkannya,

\footnotetext{
${ }^{54}$ Hukum perkawinan agamalah yang menentukan keberadaan dan keabsahan perkawinan, akta nikah dan pencatatan adalah alat bukti, dan alat bukti bukan yang menentukan sahnya perkawinan. Bagir Manan, Keabsahan dan Syarat-syarat Perkawinan Antar Orang Islam Menurut UU No. 1 Tabun 1974, Makalah disampaikan dalam seminar nasional "Problematika Hukum Keluarga dalam Sistem Hukum Nasional Antara Realitas dan Kepastian Hukum, Jakarta, 1 Agustus 2009, hlm. 1-5

${ }_{55} \mathrm{Hal}$ ini dapat dilihat dari Surat Direktorat Jenderal Pemerintahan Umum dan Otonomi Daerah No. 474.2/3069/PUOD tertanggal 19 Oktober 1995 yang menjelaskan bahwa perkawinan penghayat kepercayaan tidak dapat dicatatatkan karena perbuatan itu belum sesuai dengan hukum yang berlaku.

56 Anya Risnawati Soerya Putri, Cyntia Zella Adiyani, "Strategi Dinas Kependudukan Dan Pencatatan Sipil Dalam Meningkatkan Kepemilikan Akta Perkawinan Masyarakat Suku Akit di Kabupaten Kepulauan Meranti Provinsi Riau", Jurnal Dukcapil Kependudukan dan Catatan Sipil, Program Studi Administrasi Kependudukan dan Catatan Sipil, Fakultas Manajemen Pemerintahan, Institute Pemerintahan Dalam Negeri, Vol. 6 , No. 1 Juni 2018, hlm. 95.
} 
sehingga dengan adanya putusan $\mathrm{MK}$ ini, maka ikut mendukung dan menegaskan ditegakannya Pasal 2 ayat (1) Undang-Undang Perkawinan. Harapannya adalah segala bentuk pencatatan bagi penghayat kepercayaan tidak perlu lagi melampirkan penetapan dari Pengadilan sebagai bentuk syarat pencatatan. ${ }^{57}$ Mengingat perkawinan yang dilakukan adalah perkawinan yang diakui oleh konstitusi. Oleh karena itu penulis berpendapat bahwa terjadi kesesuaian antara amar putusan MK dan penegakan pada Pasal 2 ayat (1) Undang-Undang Perkawinan.

Kesesuaian ini merupakan perwujudan prinsip maslahah yang ada pada putusan MK. Artinya putusan MK ikut mendukung penegakan terhadap penggunaan dasar hukum kepercayaan sebagai bentuk sahnya perkawinan. Nilai maslahah yang ada adalah sejalan dengan prinsip maqasih syariah yaitu semangat dalam menghargai dan menjaga hak dan kebebasan dalam beribadah yang diyakini. ${ }^{58} \mathrm{Hal}$ ini merupakan perwujudan dari maqasid syariah berupa konteks menjaga agama (hifzh al-adin). ${ }^{59}$ Mengingat perkawinan adalah hubungan ibadah dalam konteks sesama manusia, jadi pengakuan sahnya perkawinan yang didasari nilai kepercayaan adalah wujud maslahat. Dan pengakuan itu dimotori dengan hadirnya putusan MK tersebut. Tentunya putusan MK No. 97/PUUXIV/2016 menciptakan kepastian hukum yang akan berdampak pada hak dan kewajiban dalam hubungan perkawinan. Hak kewajiban tersebut mendapatkan perlindungan dan pengakuan hukum dari Negara seperti dalam hubungan perkawinan adalah terkait harta benda, status anak dan hak alimentasi.

\section{Putusan Mahkamah Konstitusi Bernilai Maslahah bagi Umat Beragama}

Jika diperhatikan dari sudut pandang umat beragama, putusan MK ini berdampak pada terwujudnya kepastian hak-hak beragama di Indonesia. Hal ini

${ }^{57}$ Untuk mencegah kekosongan hukum akibat kepercayaan tidak diakui sebagai agama, maka mahkamah Agung mengeluarkan Surat Ketua Mahkamah Agung No. 72/MA/IV/1981 tertanggal 20 April 1981 agar pencatatan penghayat kepercayaan dapat dilakukan di kantor catatan sipil dengan melakukan permohonan ke pengadilan negeri setempat sebagai dasar hukum yang memerintahkan kantor catatan sipil dapat mencatatkan perkawinan.

58 Salah satu Maqasid syariah yang dimaksud adalah dalam konteks menjaga agama (hifzh al-din) lihat pada Prawitra Thalib Lutfansyah, Syariah, Konsep dan Hermeneutika, Mediatama, Surabaya, 2013, hln. 70-72.

59 Bila diperhatikan lebih lanjut, pencatatan perkawinan tidak hanya menjaga agama dan keyakinan seseorang, tetapi juga: menjaga diri, akal, dan harta mengingat akibat yang terjadi bila suatu hubungan perkawinan telah dicatatkan. 
terwujud dengan adanya kepastian agama dan keyakinan keduanya sudah dapat ditunjukkan pada kolom identitas warga negara. Dengan adanya kepastian ini maka masyarakat dapat memastikan kawan bergaulnya itu seorang yang beragama atau penghayat kepercayaan. Mengingat salah satu dampak dari pergaulan adalah terjadinya suatu keinginan untuk melakukan perkawinan antara laki-laki dan wanita. Dengan mengetahui identitas keyakinan yang dianutnya, maka warga negara Indonesia dapat mencegah adanya kesalahpahaman pada saat hendak melangsungkan perkawinan. ${ }^{60}$ Seperti contoh adalah bila ada seorang yang beragama Islam didalam identitasnya, tetapi diketahui ia menganut aliran kepercayaan, hal ini terjadi karena ia menutupi keyakinannya dan mencantumkan kolom agama tertentu demi kemudahan akses publik. ${ }^{61}$ Ketika melangsungkan perkawinan diketahui ia tidak melakukan ritual agama Islam sebagaimana identitas pada KTP, melainkan melakukan ritual kepercayaannya. Hal semacam ini dapat diminimalkan atau dihilangkan dengan adanya pengakuan hak sipil terhadap penghayat kepercayaan, sehingga potensi untuk melangsungkan perkawinan perbedaan agama dan kepercayaan juga dapat diminimalkan.

Pada putusan ini, hakim seakan menggunakan pemikiran Najmuddin At-Thufi dalam mengidentifikasi judicial review antara masyarakat beragama dan penghayat kepercayaan, yaitu mencari solusi terhadap potensi terjadinya pergaulan dan hubungan perkawinan. Dengan keyakinan hakim menetapkan bahwa penghayat kepercayaan dapat dicantumkan dalam kolom identitas, maka dapat menjadikan kebenaran identitas yang berdampak pada kemanfaatan pada saat pergaulan. Sehingga dapat diketahui agama dan keyakinan seseorang di Indonesia agar tidak tercipta perkawinan antar pemeluk agama dan keyakinan yang berbeda.

Hal ini patut menjadi perhatian, mengingat perkawinan beda agama dan keyakinan merupakan hal yang belum ditentukan di Indonesia, artinya tidak ada ketentuan dan larangannya. Saat ini bila terjadi perkawinan beda agama maka itu

${ }^{60}$ Agama dan kepercayaan adalah unsur yang terpisah meskipun diakui keberadaannya di Indonesia lihat pada Moh. Soehadha, "Kebijakan pemerintah tentang agama resmi serta implikasinya", Jurnal Esensia, vol. 1 No. 1, 2004, hlm. 100-101.

${ }^{61}$ Organisasi Penghayat kepercayaan yang tersebar di Indonesia sebagian dari mereka dibedakan atas penghayat yang beragama dan tidak beragama, tetapi sebagian besar dari mereka memeluk salah satu agama yang diakui di Indonesia, lihat pada Heru Susetyo, "Pencatatan Perkawinan Bagi golongan penghayat", Jurnal Hukum dan pembangunan, FH Universitas Indonesia, nomor 1-3 tahun XXVIII, edisi januari - juni,1998, hlm. 154. 
tidak serta merta dapat dilakukan pencatatan perkawinan, melainkan memerlukan izin penetapan dari pengadilan terlebih dahulu. Mahkamah Konstitusi pernah melakukan judicial review terhadap Pasal 2 Undang-Undang Perkawinan terkait perkawinan beda agama, terhadap judicial review tersebut, MK menolak permohonan tersebut melalui putusan MK No. 68/PUU-XII/2014, alasannya permohonan itu adalah menginginkan penafsiran terhadap pasal 2 ayat (1) itu dikembalikan kepada masing-masing calon mempelai. MK menyadari bahwa perkawinan beda agama dapat terjadi dengan salah satu sebabnya adalah penyelundupan hukum, tetapi bila menafsirkan Pasal 2 ayat (1) dikembalikan kepada masing-masing mempelai, maka itu akan menimbulkan tafsiran yang lebih variasi lagi dan menimbulkan masalah baru.

Nilai maslahah yang terjadi antara umat beragama dan penghayat kepercayaan setelah adanya putusan MK No. 97/PUU/XIV/2016 adalah adanya kepastian hak terhadap umat beragama dan kepercayaan. Kepastian ini merupakan upaya untuk mewujudkan kebaikan bagi masing-masing warga negara Indonesia sebagaimana konsep maslahah mursalah yaitu upaya untuk mencari tahu kebenaran dan kemanfaatan tanpa pernah berhenti demi kesejahteraan di dunia dan akhirat. ${ }^{62}$ Dalam hal ini penulis menilai terdapat parameter kaidah fiqih yang digunakan pada putusan MK yaitu kaidah Al-umur bi maqasidiha (segara urusan tergantung dari pada maksudnya). ${ }^{63}$ Yaitu upaya baik dari MK untuk mempertimbangkan dan memutus demi kepastian hak penghayat kepercayaan ternyata berdampak baik pula terhadap keberadaan umat beragama di Indonesia. Dimana ijtihad dari MK ini bila diperhatikan sejalan dengan tujuan syariah yaitu ketatapan hukum yang dibuat demi terciptanya kebahagiaan di dunia dan akhirat. Disamping itu, putusan MK ini menguatkan bahwa maqasih syariah pada sisi hifdzu-din telah digunakan untuk kemaslahatan di Negara Indonesia dimana Indonesia adalah negara yang mengakomodir agama dan kepercayaan. ${ }^{64}$

62 Prawitra Thalib, Pemaknaan filosofis maslahah mursalah menurut konsep hukum islam najmuddin attufi, artikel pada buku Eksistensi, fungsi, dan tujuan hukum dalam perspektif teori dan filsafat hukum dalam rangka memperingati 80 tahun guru kami Prof. Dr. Frans Limahelu, SH, LLM. Kencana, Jakarta, 2020, hlm. 82.

${ }^{63}$ Prawitra Thalib, Pemahaman terhadap pemberlakuan hukum Islam di Indonesia, jurmal Holrev, vol. 2 issue. 1 edisi March, 2018, hlm. 381.

${ }^{64}$ Prawitra Thalib, Lutfansyah, Op., Cit., hlm. 73. 


\section{Penutup}

Putusan Mahkamah Konstitusi No. 97/PUU/XIV/2016 memberikan harapan dan kepastian bagi semua golongan umat beragama dan aliran kepercayaan. Hal ini ditunjukkan dengan adanya kebijakan pemerintah untuk mendata, mencatat, dan memasukkan kolom penghayat kepercayaan dalam identitas KTP di Indonesia. Hal ini merupakan putusan yang bernilai maslahah, mengingat bertahun-tahun penghayat kepercayaan tidak diakui keberadaan keyakinannya karena pemaknaan agama hanya berlaku bagi agama yang diakui menurut peraturan perundangundangan. Aliran kepercayaan tidak mendapatkan pengakuan bila merujuk dari ketentuan perundang-undangan yang ada, sehingga antara agama dan kepercayaan, kepercayaan menjadi keyakinan yang terpinggirkan. Putusan MK memiliki nilai maslahah bila dianalisa menggunakan konsep maslahah dalam pemikiran hukum Islam, mengingat putusan MK itu sejalan dengan prinsip maslahah mursalah yaitu (1) suatu ketetapan hukum yang dibuat untuk memberikan kemanfaatan dan kesejahteraan bagi manusia, (2) tidak melanggar dalil dalam Al-quran dan hadis tetapi hal ini membawa solusi bagi umat beragama pada umumnya dan umat Islam pada khususnya dalam hal pergaulan dan perkawinan. Poin maslahah itu bila direfleksikan dalam perbuatan hukum maka hal itu terwujud pada antara lain: (1) pengakuan hak, (2) pengakuan mendapatkan akses hak untuk pelayanan publik, (3) pelayanan publik pada pencatatan perkawinan sebagai bentuk kepastian, (4) merupakan perintah dalam Undang-Undang Perkawinan, (5) kepastian hukum menimbulkan hak dan kewajiban bagi pasangan (5) pencatan perkawinan menimbulkan perlindungan, (7) negara wajib memberikan perlindungan bagi warganya.

\section{Daftar Pustaka}

\section{Buku}

al-Qardawi, Yusuf, Al-Ijtihad Al-Mu'ashir Baina Al-Indibat Wa Al-Infirat, Dar-al tauzi wa al-Nasyr al-Islamiyyah, 1994.

al-Zuhayli, Wahbah, Ushul al-figh al-Islam wa Adillatuhu, Dar al-fikr, Beirut, 1986. Asmawi, Perbandingan Ushul Fiqih, Amzah, Jakarta, 2013.

Departemen Pendidikan dan Kebudayaan, Kamus Besar Bahasa Indonesia, Balai Pustaka, Jakarta, 1996. 
Doe, Norman, Law and Religion in Europe, A Comparative Introduction, Oxford University press, Oxford, 2011.

Hadikusuma, Hilman, Hukum Perkawinan Indonesia Menurut: perundangan Hukum Adat Hukum Agama, Mandar Maju, Bandung, 2003.

Haroen, Nasrun, Ushul Figh 1, cetakan 1, Logos, Jakarta, 1996.

Manan, Abdul, Reformasi Hukum Islam di Indonesia Tinjauan Dari Aspek Metodologis, Legalisasi, dan Yurisprudensi, cetakan 2, Raja Grafindo Persada, Jakarta, 2013.

Marzuki, Peter Mahmud, Penelitian Hukum, Prenada Media Group, Jakarta, 2005.

Mamudji, Sri, et, al., Metode Penelitian dan Penulisan Hukum, Badan Penerbit Fakultas Hukum Universitas Indonesia, Jakarta, 2005.

Nurudin, Amir, Azhari akmal, Hukum perdata islam di Indonesia, kencana prenada media group, Jakarta, 2004.

Projodikoro, Wirjono, Azas-azas hukum perdata, Sumur Bandung, Bandung, cetakan IX, 1983.

Sanjaya, Umar Haris, Hukum Perkawinan Islam di Indonesia, Seri Buku Ajar, Gama Media, Yogyakarta, 2017.

Soekanto, Soerjono, Sri Mamudji, Penelitian Hukum Normatif Suatu Tinjauan Singkat, Raja Grafindo Persada, cet. 10, Jakarta, 2007.

Soergjerd, Caroline, Reconstruction Marriage, The legal status of relationship In changing society, Intersentia, Cambridge, 2012.

Syarifuddin, Amir, Ushul Fiqh Jilid 2, cetakan 4, Kencana, Jakarta, 2008.

Thalib, Prawitra, Syariah, Konsep dan Hermeneutika, Lutfansyah Mediatama, Surabaya, 2013.

Thalib, Prawitra, Pemaknaan Filosofis Maslahah Mursalah Menurut Konsep Hukum Islam Najmuddin At-Tufi, artikel pada buku Eksistensi, Fungsi, Dan Tujuan Hukum Dalam Perspektif Teori Dan Filsafat Hukum Dalam Rangka Memperingati 80 Tahun Guru Kami Prof. Dr. Frans Limahelu, SH, LLM. Kencana, Jakarta, 2020.

Wardiyanta, Ijtihad Religius Ahmad al-Raisuni, Erlangga, Surabaya, 1995.

Wasman, Wardah Nuroniyah, Hukum Perkawinan Islam Di Indonesia, Perbandingan Fiqih Dan Hukum Positif, teras, Sleman, Yogyakarta, 2011

Watjik, Saleh K., Hukum Perkawinan Indonesia, Ghalia, Jakarta, 1992.

\section{Hasil Penelitian}

Andromeda, Lutfiyanti, Perkawinan Penghayat kepercayaan Sapta Darma di Surabaya, studi efektifitas pencatatan perkawinan menurut Lawrence M. Friedman, Tesis, UIN Sunan Ampel Surabaya, 2020. 
Jurnal

Asni, "Pemikiran Ijtihad Kontemporer Yusuf Qardhawi Dan Relevansinya Dengan Pembaruan Hukum Islam Di Indonesia", Jurnal Al-Adl, Vol. 6 No. 1 edisi Januari 2013.

Fawaid, Imam, "Konsep Pemikiran Ath-Thufi Tentang Mashlahah Sebagai Metode Istinbath Hukum Islam", Jurnal Lisan Al-Hal, Volume 8, No. 2 Edisi Desember 2014.

Haetami, Enden, “Perkembangan Teori Maslahah 'Izzu Al-Din Bin Abd Al-Salam Dalam Sejarah Pemikiran Hukum Islam", Jurnal Asy-Syari'ah, Vol. 17 No. 1 Edisi April 2015.

Lemming, David, "Marriage And The Law In Eighteenth Century, Hardwicke's Marriage Act Of 1753", The Historical Journal, Cambridge University press, Volume 39, issues 02, June, 1996.

Opwis, Felicitas, "Maslaha in Contemporary Islamic Legal Theory", Journal Islamic Law and Society, Vol. 12, No. 2, Koninklijke Brill NV, Leiden, 2005.

Purwanto, Muhammad Roy, "Putusan Mahkamah Konstitusi Terhadap Pasal 43 ayat (1) UU No. 1 Tahun 1974 Tentang Status Anak Di Luar Nikah Berdasarkan Mashlahah Najmuddin Al-Thufi Dekonstruksi UndangUndang Hukum Islam", Jurnal Al-Mawarid, Vol. 7 Nomor.1 Edisi FebAgust 2012.

Putri, Anya Risnawati Soerya, Cyntia Zella Adiyani, "Strategi Dinas Kependudukan Dan Pencatatan Sipil Dalam Meningkatkan Kepemilikan Akta Perkawinan Masyarakat Suku Akit di Kabupaten Kepulauan Meranti Provinsi Riau", Jurnal Dukcapil Kependudukan dan Catatan Sipil, Program Studi Administrasi Kependudukan dan Catatan Sipil, Fakultas Manajemen Pemerintahan, Institute Pemerintahan Dalam Negeri, Vol. 6, No. 1 Juni 2018.

Siregar, Gomgom T, et all, "Kebangkitan Hak-Hak Sipil Penghayat Kepercayaan Parmalim Pasca Pasal 61 Ayat (1) Putusan Mahkamah Konstitusi Nomor 97 /PUU-XIV/2016 Di Kota Medan", Jurnal Rectum, volume 2, nomor 2, edisi Juli 2020.

Soehadha, Moh., “Kebijakan Pemerintah Tentang Agama Resmi Serta Implikasinya", Jurnal Esensia, vol. 1 No. 1, 2004.

Sukirno, "Rekonstruksi Pencatatan Perkawinan Bagi Penghayat Kepercayaan Komunitas Adat", Jurnal Hukum Progresif, vol. 7 No.2 edisi Oktober 2019.

Susetyo, Heru, "Pencatatan Perkawinan Bagi Golongan Penghayat", Jurnal Hukum dan pembangunan, FH Universitas Indonesia, Nomor 1-3 Tahun XXVIII, edisi Januari - Juni, 1998.

Syafei, Muhammad, "Ambiguitas Hak Kebebasan Beragama Di Indonesia Dan Posisinya Pasca Putusan Mahkamah Konstitusi", Jurnal Konstitusi, Vol. 08, No. 5, Edisi Desember 2011. 
Thalib, Prawitra, "Pemahaman Terhadap Pemberlakuan Hukum Islam Di Indonesia", Jurmal Holrev, vol. 2 issue. 1 edisi March, 2018.

Zuhdi, Muhammad Harfin, "Formulasi teori Al-mashlahah dalam paradigm pemikiran hukum Islam Kontemporer, Proceeding Annual International Conference on Islamic Studies, XIV, STAIN Samarinda, 2014

\section{Makalah/Pidato}

Manan, Bagir, Keabsahan dan Syarat-syarat Perkawinan antar orang islam Menurut UU No. 1 Tahun 1974, Makalah disampaikan dalam seminar nasional "Problematika Hukum Keluarga dalam Sistem Hukum Nasional Antara Realitas dan Kepastian Hukum", Jakarta, 1 Agustus 2009.

Wignjosoebroto, Soetandyo, Masalah Pluralisme dalam pemikiran dan kebijakan perkembangan hukum nasional, pengalaman Indonesia, makalah seminar nasional pluralisme hukum, Pluralisme Hukum Perkembangan Di Beberapa Negara, Sejarah Pemikirannya Di Indonesia Dan Pergulatannya Dalam Gerakan Pembaharuan Hukum, Universitas Al-Azhar, Jakarta, 2006.

\section{Berita Internet}

Kolom agama di ktp dan kesetaraan hak untuk penghayat kepercayaan, lihat pada http://lipi.go.id/berita/kolom-agama-di-ktp-dan-kesetaraan-hakuntuk-penghayat-kepercayaan/21741 diakses pada 26 September 2020

https: / / nasional.tempo.co/read/1178325/begini-prosedur-mendapat-ktp-bagipenganut-aliran-kepercayaan diakses pada 17 September 2020.

https:/ / majalah.tempo.co/read/agama/124492/tujuh-petunjuk-menuju-waskita, diakses pada 18 September 2020. 